Article

\title{
The Effect of TiC Additive on Mechanical and Electrical Properties of $\mathrm{Al}_{2} \mathrm{O}_{3}$ Ceramic
}

\author{
Sergey N. Grigoriev, Marina A. Volosova, Pavel Y. Peretyagin, Anton E. Seleznev, \\ Anna A. Okunkova * and Anton Smirnov* \\ Moscow State University of Technology STANKIN, Vadkovsky per. 1, Moscow 127055, Russia; \\ s.grigoriev@stankin.ru (S.N.G.); m.volosova@stankin.ru (M.A.V.); p.peretyagin@stankin.ru (P.Y.P.); \\ a.seleznev@stankin.ru (A.E.S.) \\ * Correspondence: a.okunkova@stankin.ru (A.A.O.); a.smirnov@stankin.ru (A.S.); Tel.: +7-499-973-23-70 (A.S.)
}

Received: 29 October 2018; Accepted: 20 November 2018; Published: 26 November 2018

Featured Application: The work aimed to develop a new class of electrically conductive ceramics, which can be recommended for the production of cutting inserts in tools for the machining of superhard hardened steels, hard-to-machine materials, composites and other materials used in mechanical engineering.

\begin{abstract}
In this study the influence of $\mathrm{TiC}$ content on the mechanical and electrical properties of $\mathrm{Al}_{2} \mathrm{O}_{3}$ - $\mathrm{TiC}$ composites containing 30 and 40 vol.\% TiC were investigated. The Vickers hardness and fracture toughness of the composites increased with the addition of $\mathrm{TiC}$ phase. The composite with $40 \mathrm{vol} \% \mathrm{TiC}$ showed the highest flexural strength $(687 \pm 39 \mathrm{MPa})$, fracture toughness $\left(7.8 \pm 0.4 \mathrm{MPa} \cdot \mathrm{m}^{1 / 2}\right)$ and hardness $(22.3 \pm 0.3 \mathrm{GPa})$ with a homogeneous distribution of the second phase within the ceramic matrix. Besides enhanced mechanical properties, it was found that ceramic composites with more than $30 \mathrm{vol} . \%$ TiC fabricated by the spark plasma sintering possess sufficient electrical conductivity for electrical discharge machining as well. Therefore, they do not limit the flexibility of the shape, and any intricate parts can be easily made with these composites which can be recommended for the production of cutting inserts in the tools for machining of superhard hardened steels, hard-to-machine materials, composites and other materials used in mechanical engineering.
\end{abstract}

Keywords: alumina; titanium carbide; composites; spark plasma sintering; microstructure; mechanical properties; electrical conductivity; EDM

\section{Introduction}

Although WC-Co still dominates the cutting tools market, alumina-based composite materials may be a good alternative to improve cutting speed and lower production costs [1-4]. Alumina-based ceramic tools are used due to their excellent operational properties in extreme conditions such as wear resistance, hardness and low chemical interactivity with surrounding materials [5-8]. Meanwhile, the range of applications of alumina ceramics as a structural material is limited by their low fracture toughness [9-11]. Therefore, cracks will propagate easily and can cause unpredictable failure of ceramic composites $[12,13]$. Various techniques have been proposed to enhance the mechanical performance of alumina. For instance, the addition of reinforcing phases such as ceramics, metals, and intermetallic compounds into an $\mathrm{Al}_{2} \mathrm{O}_{3}$ matrix, forming a composite material, has been proved to be an effective experimental route to improve the toughness of the ceramic matrix [14-18].

In addition, the widespread use of these materials requires a non-traditional way of manufacturing [19-22]. Today, materials are usually machined by grinding using abrasive materials or hard tools. However, machining of ceramic materials with sophisticated shapes using traditional 
machining methods is a complicated and time-consuming process due to their exceptional physical properties, especially extreme hardness.

To this end, electrical discharge machining (EDM) is a commonly applied technique to machine single-phase ceramics, cermets, and ceramic matrix composites [23-26].

However, EDM is only possible on conducting materials with an electrical resistivity below $100 \div 300 \Omega \cdot \mathrm{cm}[27-29]$.

Secondary phase $\mathrm{TiC}$ was incorporated into a ceramic matrix to improve the fracture toughness and electrical conductivity of alumina-based composites.

Also, when traditional sintering methods are used to fabricate $\mathrm{Al}_{2} \mathrm{O}_{3}$-TiC composites, a high temperature is necessary to obtain nearly fully dense material. However, higher sintering temperature and sintering time lead to undesirable grain growth which may reduce the operational properties of the material [30-32].

Furthermore, the following chemical reactions between $\mathrm{Al}_{2} \mathrm{O}_{3}$ and $\mathrm{TiC}[33,34]$,

$$
\mathrm{Al}_{2} \mathrm{O}_{3}+\mathrm{TiC}=\mathrm{Al}_{2} \mathrm{O} \downarrow+\mathrm{TiO}+\mathrm{CO} \uparrow
$$

can occur at high temperatures and can cause porosity which also causes deterioration in the mechanical properties. Therefore, to decrease the sintering temperature spark plasma sintering (SPS) was used as an alternative consolidation method.

Using this novel technology facilitates fast consolidation, allows fabrication of fully dense composites and avoids grain growth [35-40].

SPS also offers considerable advantages such as faster and shorter processing time compared to conventional sintering methods, due to simultaneous application of mechanical pressure and electric pulses [41-43].

Therefore, the goals of the present investigation are twofold: the fabrication of electrically conductive ceramic composites with full density, and analysis of the effect of TiC phase addition on their mechanical performance and electrical conductivity.

\section{Materials and Methods}

The following raw powders were used in the experiments:

(1) a- $\mathrm{Al}_{2} \mathrm{O}_{3}$ corundum A16SG (Alcoa, New York, NY, USA), with an average particle diameter of $d_{50}=0.53 \mu \mathrm{m}$,

(2) $\mathrm{TiC}$ (Plasmotherm, Moscow, Russia), with 99.5\% purity and an average particle diameter of $d_{50}=0.6 \mu \mathrm{m}$.

Powder mixtures with different amounts of $\mathrm{TiC} 30$ and 40 vol.\% were mixed in a multidirectional Turbula shaker mixer (Eskens B.V., Alphen aan den Rijn, Netherlands) in ethanol in a polyethylene container at $150 \mathrm{rpm}$ for $24 \mathrm{~h} \mathrm{[17].}$

Lyophilizer FreeZone2.5 (LabConco, Kansas, MO, USA) was used for the drying of the obtained slurries to avoid agglomerates of $\mathrm{TiC}$ phase in the alumina matrix. The collector temperature was set at $-50 \pm 2{ }^{\circ} \mathrm{C}$, while the shell temperature was $+23 \pm 2{ }^{\circ} \mathrm{C}$ and the chamber pressure was $0.02 \pm 0.01$ mbar during the entire process. Also, this method allows powders to be sintered without sieving [44]. The powders were sintered with a KCE FCT-H HP D-25 SD spark plasma sintering machine (FCT Systeme $\mathrm{GmbH}$, Rauenstein, Germany) at $1400{ }^{\circ} \mathrm{C}$ with a heating rate of $100{ }^{\circ} \mathrm{C} \cdot \mathrm{min}^{-1}$, under a uniaxial pressure of $80 \mathrm{MPa}$ in a vacuum.

The final temperature and pressure were maintained for $3 \mathrm{~min}$ and 20-mm-diameter, 2-4-mm-thick as-sintered sample disks were labeled depending on their TiC content.

XRD measurements were carried out in an Empyrean diffractometer (PANalytical, Almelo, Netherlands) ranging from $25^{\circ}$ to $70^{\circ}$. The step size was $0.05^{\circ}$ with a scan speed of $0.06^{\circ} / \mathrm{min}$. The diffractometer used $\mathrm{Cu} \mathrm{K} \alpha$ radiation $(\lambda=1.5405981)$, working at $60 \mathrm{kV}$ and with an intensity 
of $30 \mathrm{~mA}$. Density measurements $(\rho)$ of the sintered specimens were done in distilled water using Archimedes' principle and compared with the theoretical values $\left(3.89 \mathrm{~g} / \mathrm{cm}^{3}\right.$ for $\mathrm{Al}_{2} \mathrm{O}_{3}$ and $4.93 \mathrm{~g} / \mathrm{cm}^{3}$ for $\mathrm{TiC}$, respectively) calculated from the rule of mixture.

A scanning electron microscope (SEM) VEGA3 (Tescan, Brno, The Czech Republic) was used for characterization of surfaces polished down to $1 \mu \mathrm{m}$. The energy-dispersive $\mathrm{X}$-ray spectroscopy (EDS) spectra were conducted in specific regions at $20 \mathrm{kV}$ voltage and $12 \mu \mathrm{A}$ beam current for $5 \mathrm{~min}$ to obtain well-resolved $\mathrm{Y}-\mathrm{K} \alpha$ and $\mathrm{Zr}-\mathrm{K} \alpha$ peaks for the chemical microanalysis of sintered samples.

Ten Vickers impressions were carried out in the surfaces of each of the tested samples, which had previously been polished down $1 \mu \mathrm{m}$. The $9.8 \mathrm{~N}$ load was applied for ten seconds by a Vickers diamond indenter Leco 100-A (Leco Corp., St. Joseph, MI, USA). The HV magnitude was calculated as follows:

$$
H V=0.1891 \frac{P}{d^{2}}
$$

where $P$ is the applied load, $\mathrm{N} ; d$ is the average length of the two diagonals, mm. SEM was used for evaluation of the size of the indentations.

The values of fracture toughness $\left(\mathrm{K}_{1 \mathrm{c}}\right)$ were also estimated by Vickers microindentation. The cracks were observed at $294 \mathrm{~N}$ and load holding time was set to $10 \mathrm{~s}$.

At least 10 indentations tests were performed per specimen. The fracture toughness was calculated using the formula presented in Miranzo [45]. The flexural strength $\left(\sigma_{f}\right)$ was evaluated through a biaxial bending test. Each sample was placed onto a device with three balls of $3 \mathrm{~mm}$ in diameter that were made of hardened steel and disposed on a holder (10 mm diameter) at $120^{\circ}$ to each other. The load was applied with a $5 \mathrm{kN}$ universal testing machine (Auto Graph AG-X, Shimadzu Corp., Kyoto, Japan) using a plain head of $1.2 \mathrm{~mm}$ in diameter at a speed of $1 \mathrm{~mm} \cdot \mathrm{min}^{-1}$ up to failure. The specimen thickness was measured at the breakage point. 12 specimens were tested to obtain the average strength value. A review of the procedure is reported in Smirnov [46].

The electrical resistance of $\mathrm{Al}_{2} \mathrm{O}_{3}$-TiC ceramic composites sintered via SPS was determined by a four-wire Kelvin connection scheme using a separate current source, Keithley 6220, and a two-channel nanovoltmeter, Keithley 2182A (Keithley Instruments, Solon, OH, USA) [47,48]. The four-point set-up comprises four equally spaced tungsten carbide electrodes. These electrodes have a diameter of $0.4 \mathrm{~mm}$ and are separated by a distance of $1 \mathrm{~mm}$. A power source with a high internal resistivity sends a constant current through the two outer electrodes. An ammeter was used for measurement of the current output. The approbation of electrical discharge machining ability was conducted on 4-axis CNC-machine M500SG (Seibu Electric \& Machinery Co., Fukuoka, Japan). A brass wire, CuZn35 with a diameter of $d_{w}=0.25 \mathrm{~mm}$, was used during the experiments. The conductivity of the deionized water was $0.1 \mu \mathrm{S} \cdot \mathrm{cm}^{-1}$; electric voltage $V_{o}=270 \mathrm{~V}$; and current intensity $I_{e}=0.05 \mathrm{~A}$. The frequency of the working impulses was $f_{w}=0.2 \mathrm{MHz}[49,50]$.

\section{Results}

\subsection{Characterization of the Samples and their Mechanical Properties}

A representative $X$-ray diffraction pattern corresponding to the sintered and polished $\mathrm{Al}_{2} \mathrm{O}_{3}-\mathrm{TiC}$ composites is shown in Figure 1. The pattern reveals that no contamination was detected, nor the presence of side reactions along the sintering of the powder.

The polished and fractured microstructure of dense $\mathrm{Al}_{2} \mathrm{O}_{3}-\mathrm{TiC}$ composites was studied by SEM on $1 \mu \mathrm{m}$ polished surfaces, where the dark phases are for alumina grains, and the light ones are for titanium carbide grains (Figure 2).

The microstructure analyses confirmed that the density of composites was the same as the theoretical value since no pores were observed. 


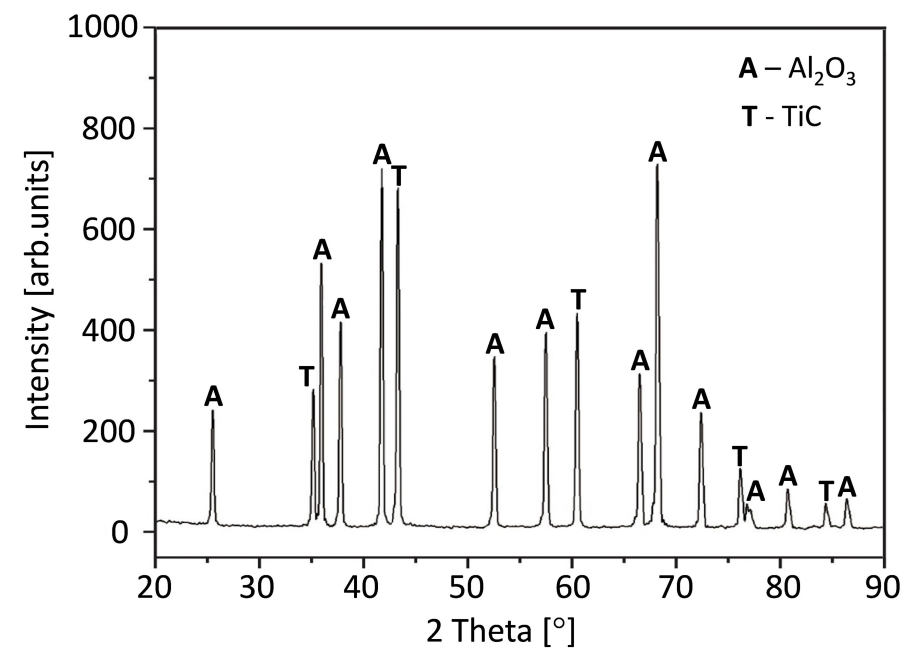

Figure 1. XRD pattern of the polished surface of $\mathrm{Al}_{2} \mathrm{O}_{3}-\mathrm{TiC}$ composites, where $\mathrm{A}$ is $\alpha$-alumina, and $\mathrm{T}$ is $\mathrm{TiC}$.

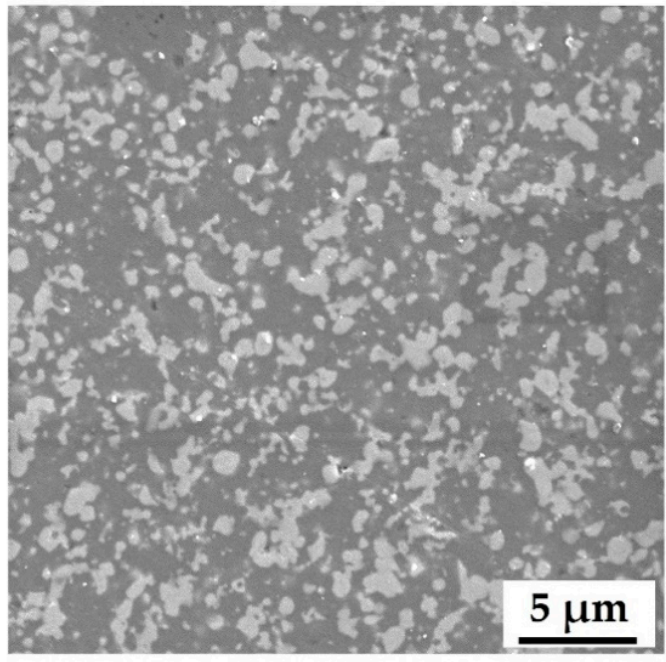

(a)

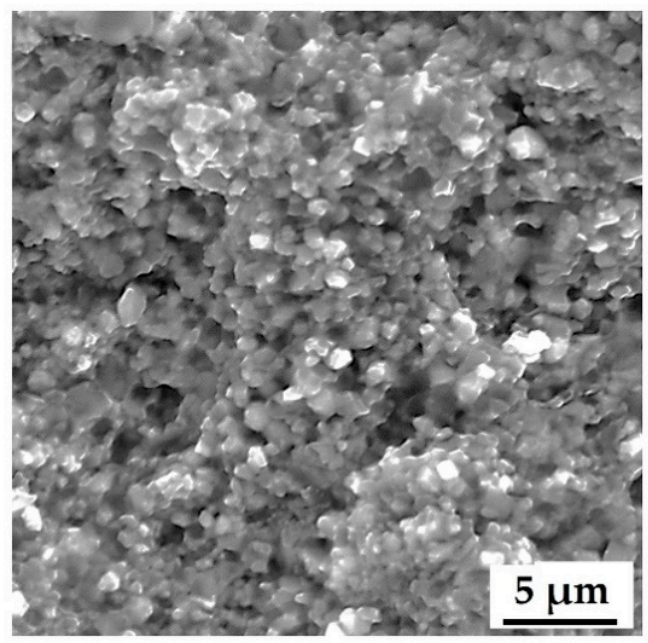

(c)

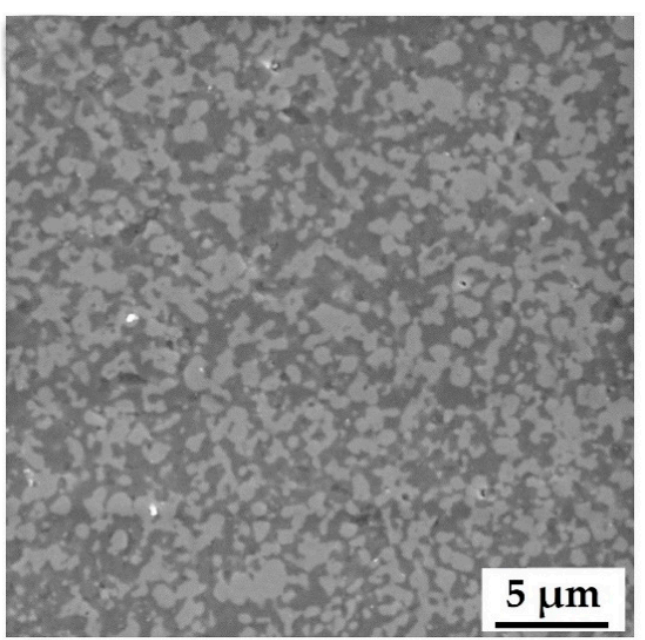

(b)

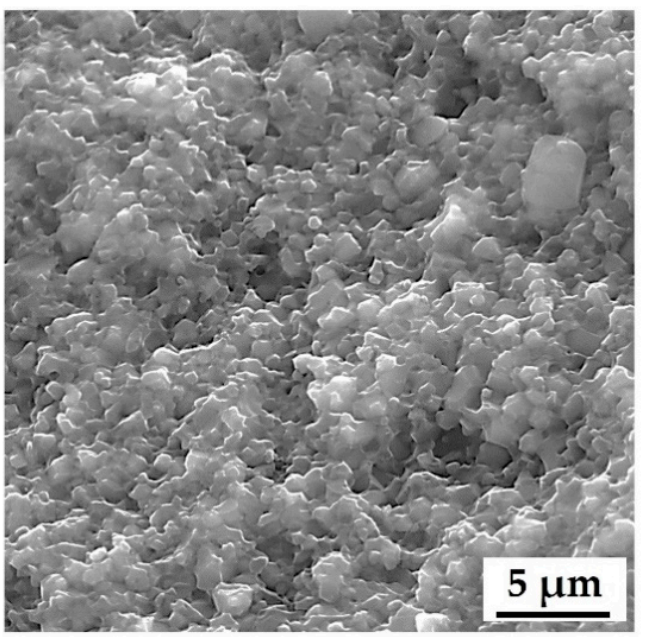

(d)

Figure 2. SEM micrographs of $\mathrm{Al}_{2} \mathrm{O}_{3}-\mathrm{TiC}$ composites: (a) polished surface of the sample with 30 vol.\% $\mathrm{TiC}$; (b) polished surface of the sample with $40 \mathrm{vol} \% \mathrm{TiC}$; (c) fractured surface of the sample with $30 \mathrm{vol} . \%$; (d) fractured surface of the sample with 40 vol.\%. In the figure, alumina is dark, and TiC is light. 
Figure 3 shows energy-dispersive X-ray spectroscopy (EDX) maps of the polished surface of $\mathrm{Al}_{2} \mathrm{O}_{3}-40$ vol.\% TiC composite, showing a homogeneous distribution of the elements throughout the sample and, consequently, indicating that the wet processing route was suitable for the fabrication of bulk materials. The main mechanical properties of sintered composites in comparison with a few properties of $\mathrm{Al}_{2} \mathrm{O}_{3}-\mathrm{TiC}$ (40 vol.\%) cutting ceramic (K01, ISO) are shown in Table 1.

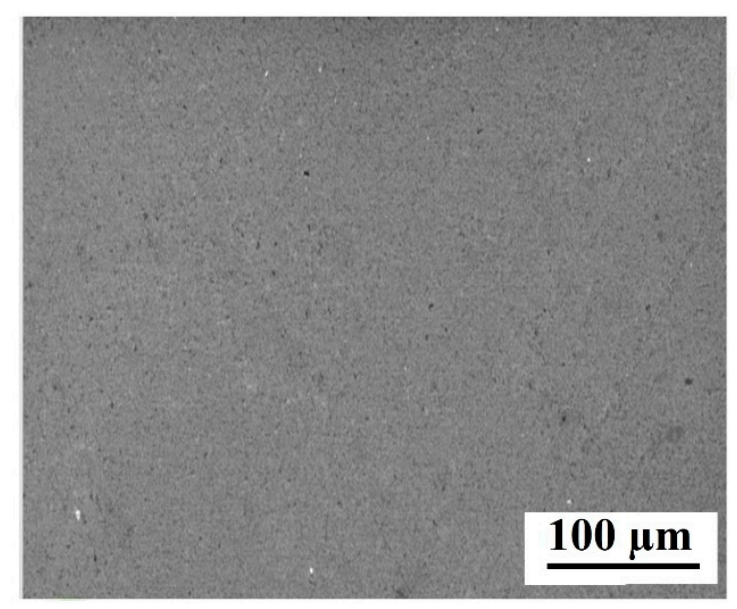

(a)

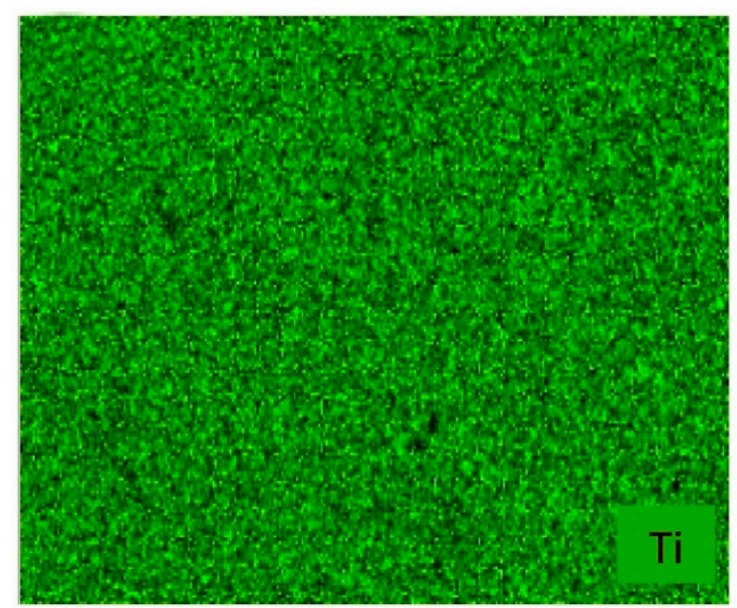

(c)

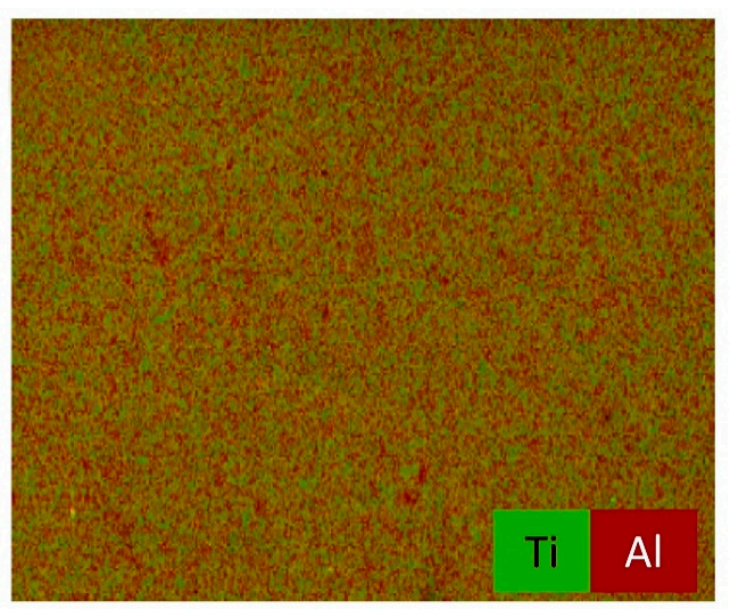

(b)

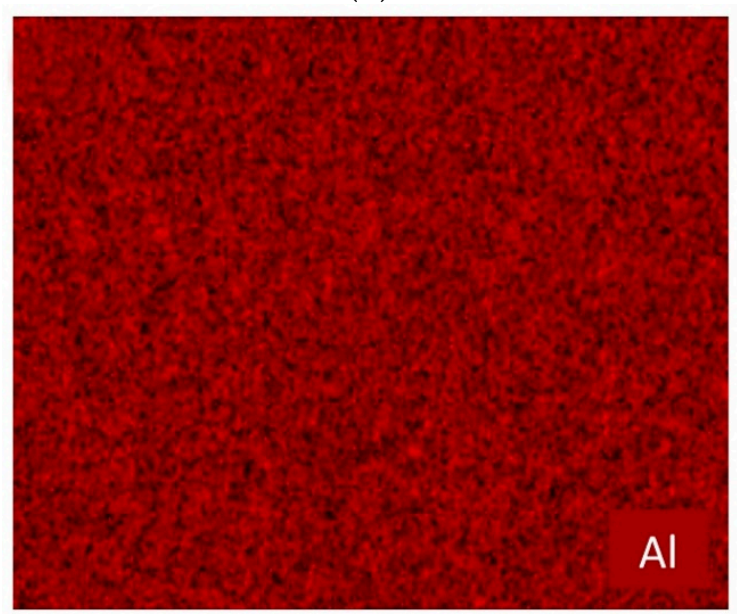

(d)

Figure 3. The $\mathrm{Al}_{2} \mathrm{O}_{3}-40$ vol.\% TiC composite: (a) polished surface of the sample; (b) combination map for phases in a composite; (c) distribution map of X-ray of individual element Ti K $\alpha$; (d) distribution map of X-ray of individual element $\mathrm{Al} \mathrm{K} \alpha$.

Table 1. Mechanical properties of $\mathrm{Al}_{2} \mathrm{O}_{3}-\mathrm{TiC}$ composites with 30 and $40 \mathrm{vol}$. $\mathrm{TiC}$.

\begin{tabular}{|c|c|c|c|c|}
\hline Material & $\begin{array}{c}\text { Density }^{1} \\
{\left[\% \rho_{\mathrm{th}}\right]}\end{array}$ & $\begin{array}{c}\text { Flexural Strength }^{2} \\
\sigma_{f}[\mathrm{MPa}]\end{array}$ & $\begin{array}{c}\text { Hardness } \mathrm{HV}^{2} \\
{[\mathrm{GPa}]}\end{array}$ & $\begin{array}{c}\text { Fracture Toughness } \\
K_{I c}\left[\mathrm{MPa} \cdot \mathrm{m}^{1 / 2}\right]\end{array}$ \\
\hline $\mathrm{Al}_{2} \mathrm{O}_{3}-30$ vol. $\% \mathrm{TiC}$ composite & 99 & $643 \pm 48$ & $22.8 \pm 0.4$ & $7.1 \pm 0.3$ \\
\hline $\mathrm{Al}_{2} \mathrm{O}_{3}-40$ vol.\%TiC composite & 99 & $687 \pm 39$ & $23.3 \pm 0.3$ & $7.8 \pm 0.4$ \\
\hline $\begin{array}{c}\mathrm{Al}_{2} \mathrm{O}_{3}-40 \text { vol. } \% \mathrm{TiC}^{3} \text { cutting } \\
\text { ceramic }[51-53]\end{array}$ & - & $\sim 637.0$ & 13.5-14.0 & $3-5$ \\
\hline
\end{tabular}

${ }^{1}$ Theoretical value; ${ }^{2}$ experimental value; ${ }^{3}$ given for reference. 
The hardness of the composites increases as the $\mathrm{TiC}$ content increases because $\mathrm{TiC}$ is relatively harder than $\mathrm{Al}_{2} \mathrm{O}_{3}$. The fracture toughness of the samples increases as the proportion of $\mathrm{TiC}$ additive increase in the samples. The inclusion of second phase particles in a matrix can hinder crack propagation and consequently increase toughness. Different toughening mechanisms, induced by interaction between the crack and microstructure, such as crack deflection and grain bridging by TiC grains, were observed and are presented in Figure 4, where the dotted red lines and solid yellow lines indicate the area where close-up was taken. The red and yellow arrows show the crack bridging and crack deflection by $\mathrm{TiC}$. These mechanisms are effectively increasing the crack propagation resistance, resulting in an improvement in the fracture toughness.

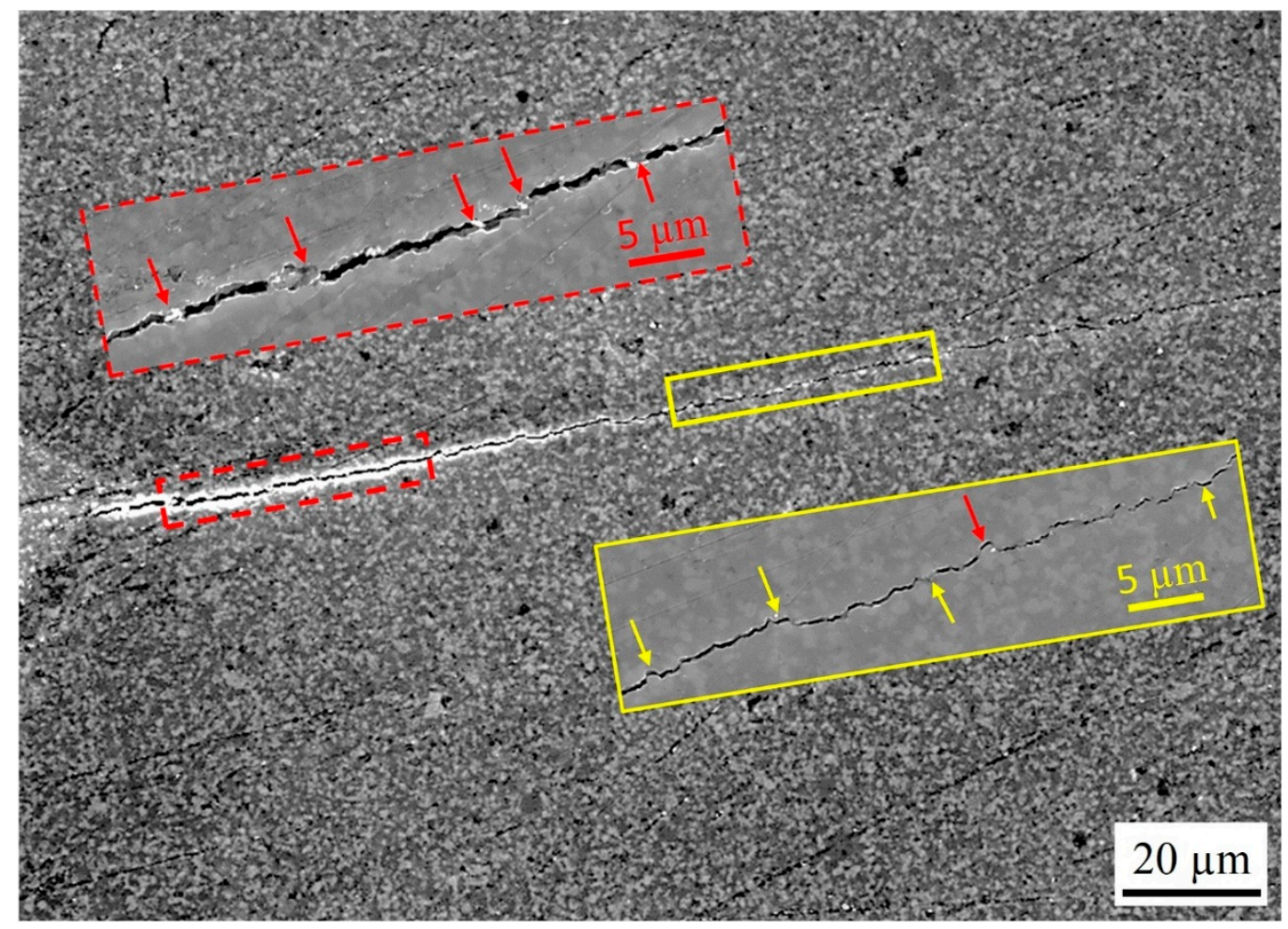

Figure 4. Vickers indentation crack induced on the surface of the $\mathrm{Al}_{2} \mathrm{O}_{3}-40$ vol.\% $\mathrm{TiC}$ composite.

\subsection{Electrical Properties and Electrical Discharge Machining of the Samples}

The measured and calculated electrical properties of sintered composites in comparison with the $\mathrm{Al}_{2} \mathrm{O}_{3}-\mathrm{TiC}(40$ vol.\%) cutting ceramic (K01, ISO), TiC particles and brass wire material CuZn35 (426-1, ISO) are shown in Table 2.

Table 2. Electrical properties of $\mathrm{Al}_{2} \mathrm{O}_{3}$ - TiC composites with 30 and 40 vol. \% TiC.

\begin{tabular}{|c|c|c|c|c|}
\hline Material & $\begin{array}{c}\text { Electrical } \\
\text { Conductivity }^{1} \gamma \\
{\left[\mathrm{S} \cdot \mathrm{cm}^{-1}\right]}\end{array}$ & $\begin{array}{c}\text { Electrical } \\
\text { Conductivity } \\
{\left[\mathrm{S} \cdot \mathrm{m}^{-1}\right]}\end{array}$ & $\begin{array}{l}\text { Specific Electrical } \\
\text { Resistance }^{2} \\
\mathrm{R}\left[\Omega \cdot \mathrm{mm}^{2} \cdot \mathrm{m}^{-1}\right]\end{array}$ & $\begin{array}{c}\text { Specific Electrical } \\
\text { Resistance }^{2} \mathbf{R} \\
{[\Omega \cdot \mathrm{m}]}\end{array}$ \\
\hline $\mathrm{Al}_{2} \mathrm{O}_{3}-30$ vol. $\%$ TiC composite & $2956.3 \pm 9.6$ & 295,630 & 3.382 & $3.38 \times 10^{-6}$ \\
\hline $\mathrm{Al}_{2} \mathrm{O}_{3}-40$ vol. $\% \mathrm{TiC}$ composite & $16,985.2 \pm 38.4$ & $1,698,520$ & 0.589 & $5.89 \times 10^{-7}$ \\
\hline $\begin{array}{c}\mathrm{Al}_{2} \mathrm{O}_{3}-40 \text { vol. } \% \mathrm{TiC}^{3} \text { cutting } \\
\text { ceramic }[53,54]\end{array}$ & 2849.0 & 284,900 & 3.510 & $3.51 \times 10^{-6}$ \\
\hline $\operatorname{TiC}^{3}[21,22]$ & $16,667.0$ & $1,666,700$ & 0.600 & $6.0 \times 10^{-7}$ \\
\hline $\mathrm{CuZn} 35^{3}[55]$ & $135,135.0$ & $13,513,500$ & 0.074 & $7.4 \times 10^{-8}$ \\
\hline
\end{tabular}

${ }^{1}$ Experimental value measured in absolute units; ${ }^{2}$ calculated value; ${ }^{3}$ given for reference. 
The closest value of specific electrical resistance for the produced sample of sintered $\mathrm{Al}_{2} \mathrm{O}_{3}-\mathrm{TiC}$ ceramic with $40 \%$ vol. of TiC is for pure Titan $\left(5.56 \times 10^{-7} \Omega \cdot \mathrm{m}\right)$ [56-59]. The EDM parameters for processing graphite and titan were chosen as more common in conditions of real manufacturing, to provide adequate values of the discharge gap and frequency and duration of the pulses on the industrial CNC-machine.

Figure 5 shows the surface of the samples after electrical discharge machining, where white and yellow arrows indicate microcracking in the recast layer and initial structure of the composite, respectively.

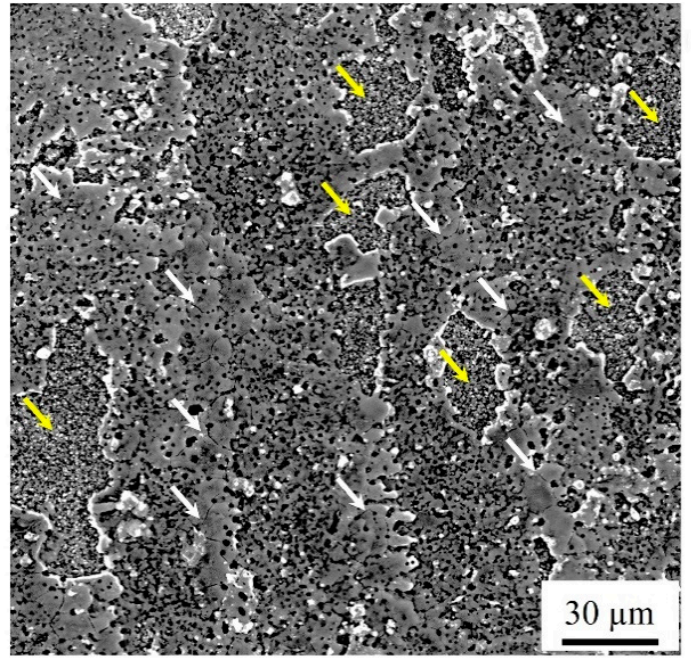

(a)

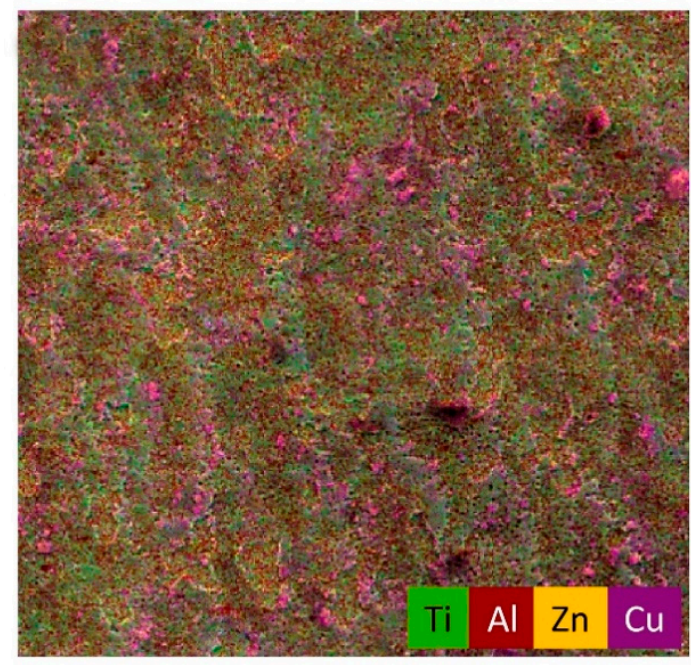

(b)

Figure 5. The surface of $\mathrm{Al}_{2} \mathrm{O}_{3}-40$ vol.\% TiC composite after electrical discharge machining: (a) image obtained on SEM; (b) (Energy-dispersive X-ray spectroscopy) EDX map of the surface.

In this figure, two different process zones are observed. In EDM the material is machined by electrical discharges without direct contact between the electrode and the workpiece that leads to the formation of plasma in the neighborhood of the machined front and causes material fusion (Figure 5a).

Consequently, there are places where the wire has caused material fusion, and the presence of surface microcracks caused by EDM was determined, especially in the recast layer. Residual stresses formed at the surface are related to an excessive heating-quenching temperature difference and lead to the formation of microcracks during the EDM process. On the other hand, there are zones where an initial structure of the composite is still observed. Also, in contrast to EDX analysis of the polished surface (Figure 3) on the machined surface (Figure 5b), the presence of $\mathrm{Cu}$ and $\mathrm{Zn}$ was observed. This can be explained by the transfer of these elements from the brass wire. The micrograph of the machined surface (Figure 5a) shows that in most cases the tiny microcracks occur only within the recast layer [60].

\section{Discussion}

\subsection{Characterization of the Samples and its Mechanical Properties}

The ceramic samples were entirely produced in the laboratories of MSTU "Stankin" with the maximum achievable homogeneity, using the spark plasma sintering method assisted by the electrical current $[17,28]$. The main SPS parameters were chosen according to the recommendations of the equipment manufacturer and based on practical experience with the equipment. The samples were of 2-4 $\mathrm{mm}$ thickness and $20 \mathrm{~mm}$ in diameter. 
As presented, the main mechanical properties of the samples showed that the samples have similar flexural strength as the sample of $\mathrm{Al}_{2} \mathrm{O}_{3}$ - TiC cutting ceramic produced industrially. At the same time, the Vickers hardness of the samples is twice as high as for their industrial analogue.

\subsection{Electrical Properties and Electrical Discharge Machining of the Samples}

It should be noted that conductors have specific electrical resistance $R<10^{-5} \Omega \cdot \mathrm{m}$ as the specific electrical resistance of dielectrics is $R>10^{8} \Omega \cdot \mathrm{m}$ [61]. Thus, the produced samples of sintered $\mathrm{Al}_{2} \mathrm{O}_{3}-\mathrm{TiC}$ ceramic are suitable for electrical discharge machining [62]. The value of specific electrical resistance for produced conductive ceramic with $30 \mathrm{vol} . \%$ of TiC is close to the value for carbon in the form of graphite $\left(8.0 \times 10^{-6} \Omega \cdot \mathrm{m}\right)[63]$.

The TiC content in the samples makes them conductive since the electrical resistance of titanium carbide is $6.0 \times 10^{-7} \Omega \cdot \mathrm{m}[21,22,64]$, which is higher than the value for the brass wire (Table 2). As the equivalent ratio of $\mathrm{TiC}$ content in the samples increases, the conductivity of the samples also increases with no loss of mechanical properties.

However, $\mathrm{TiC}$ is highly resistant to melting in the presence of metals with a low-melting-point such as copper, aluminum, brass, cast iron, etc. as its stability temperature is $3140{ }^{\circ} \mathrm{C}$ [65].

It should be noted that the primary material of the matrix of samples was alumina, which is a dielectric $[66,67]$ or an n-type semiconductor [68] with a melting point of $2044{ }^{\circ} \mathrm{C}$ and a boiling point of $2977{ }^{\circ} \mathrm{C}[22,69]$.

As the boiling point of any alloy corresponds to the highest value of the boiling point of its components, the melting point of brass will be $\sim 900{ }^{\circ} \mathrm{C}[55,70]$, and the boiling point will be $\sim 2590{ }^{\circ} \mathrm{C}$. In the same way, it can be supposed that the melting point for samples produced of the conductive ceramic will be $3140{ }^{\circ} \mathrm{C}$ as for the $\mathrm{TiC}$ component.

This means that brass wire is not suitable for electrical discharge machining of the conductive ceramic or other hard-to-melt materials. Figure 5 showed that the brass sublimated and adsorbed on the surface of the opposing electrode. The quality of the machined surface is low and demonstrates the presence of chaotic overlapped wells with a diameter of $10-15 \mu \mathrm{m}$. It can be concluded that at the moment when the temperature in the discharge channel achieves the value which is suitable for sublimation of $\mathrm{TiC}$, the brass has already evaporated, with the formation of a plasma cloud (this can be seen during processing as a series of tiny bubbles on the surface of the dielectric). Then, the discharge gap and series of impulses are disrupted [71].

The value of the discharge gap for the conductive ceramic was experimentally determined to be in the order of $0.005 \mathrm{~mm}$, which is 15 times less than the recommended value for easy-to-melt alloys such as aluminum alloy $(\sim 0.075 \mathrm{~mm})$. A value of $0.005 \mathrm{~mm}$ is difficult to control by adaptive control of EDM-machine based on monitoring electrical parameters [72]. The environmental conditions and amplitude of the wire oscillation under the impulse current may affect the accuracy of processing even during roughing [73].

Hence, use of an electrode made of tungsten can be recommended for further research, as it has higher values for melting and boiling points $\left(3410{ }^{\circ} \mathrm{C}\right.$ and $5660^{\circ} \mathrm{C}$, respectively), and a higher value of electrical resistance $\left(4.9 \times 10^{-8} \Omega \cdot \mathrm{m}\right)$ [74]. For electrical discharge machining with the profiled electrode, it may be suitable to use graphite instead of copper.

\section{Conclusions}

The results achieved in this work demonstrate that homogeneous and dense ( $>98$ th\%) alumina-titanium carbide ceramic composites (with 30 and 40 vol. \% $\mathrm{TiC}$ ) were produced following a colloidal processing route, freeze drying method and spark plasma sintering. $\mathrm{Al}_{2} \mathrm{O}_{3}-\mathrm{TiC}$ composite with 40 vol.\% TiC simultaneously improved fracture toughness $\left(7.8 \pm 0.4 \mathrm{MPa} \cdot \mathrm{m}^{1 / 2}\right)$ and hardness $(22.3 \pm 0.3 \mathrm{GPa})$ of the composites, which is twice as high as the value for traditional $\mathrm{Al}_{2} \mathrm{O}_{3}-\mathrm{TiC}$ cutting ceramic (K01, ISO). The multiple actions of reinforcement in crack deflection and bridging were observed due to the presence of $\mathrm{TiC}$ particles. 
Besides improved mechanical properties, it was found that ceramic composites also possess electrical conductivity (higher than $10^{-2} \mathrm{~S} \cdot \mathrm{cm}^{-1}$ ) and consequently, this implies EDM machinability with the required complex shapes and high accuracy. This is more efficient than conventional machining operations such as diamond grinding, polishing, and lapping. Therefore, EDM allows the production of complex shapes and the machining of developed $\mathrm{Al}_{2} \mathrm{O}_{3}$-TiC composites, combined with a high degree of automation, which significantly increase the accuracy, speed, and cost-effectiveness of manufacturing.

These composites can be processed into any intricate shape that makes it possible for them to be used in various applications, including miniaturized structures or indexable inserts for machining of hardened steel, difficult-to-machine materials, composites and other materials used in mechanical engineering.

\section{Patents}

1. Grigoriev, S.N.; Torrecillas, R.; Diaz Rodrigez, A.L.; Solis Pinargote, N.W.; Okunkova, A.A.; Volosova, M.A.; Peretyagin, P.Y.; Vladimirov, Y.G.; Loktev, M.A. Device for producing products from composite powders; RU2555303C1; Date 07.10.2015.

2. Grigoriev, S.N.; Torrecillas, R.; Diaz Rodrigez, A.L.; Solis Pinargote, N.W.; Okunkova, A.A.; Volosova, M.A.; Peretyagin, P.Y.; Vladimirov, Y.G.; Loktev, M.A. The method of obtaining nanocomposite from ceramic powder; RU2544942C1; Date 20.03.2015.

3. Grigoriev, S.N.; Volosova, M.A.; Okunkova, A.A. A method of manufacturing a shaped cutter; RU 2491156; Date 27.08.2013.

Author Contributions: Conceptualization, S.N.G. and M.A.V.; Data Curation, A.E.S. and P.Y.P.; Formal Analysis, A.A.O. and A.S.; Funding Acquisition, S.N.G.; Investigation, A.S. and P.Y.P.; Methodology, M.A.V.; Project Administration, S.N.G. and M.A.V.; Resources, A.E.S. and P.Y.P.; Software, A.E.S. and A.A.O.; Supervision, S.N.G. and M.A.V.; Validation, A.A.O.; Visualization, A.E.S.; Writing-Original Draft, A.S. and P.Y.P.; Writing-Review \& Editing, A.A.O. and A.S.

Funding: This research was funded by the Russian Science Foundation, grant number No. 18-19-00599.

Acknowledgments: The study was conducted at the Laboratories of MSTU "Stankin".

Conflicts of Interest: The authors declare no conflicts of interest.

\section{References}

1. $\mathrm{Liu}, \mathrm{J} . ; \mathrm{Li}, \mathrm{J} . ; \mathrm{Xu}, \mathrm{C}$. Interaction of the cutting tools and the ceramic-reinforced metal matrix composites during micro-machining: A review. CIRP J. Manuf. Sci. Technol. 2004, 7, 55-70. [CrossRef]

2. Kumar, A.S.; Durai, A.R.; Sornakumar, T. Machinability of hardened steel using alumina-based ceramic cutting tools. Int. J. Refract. Met. H 2003, 21, 109-117. [CrossRef]

3. Gevorkyan, E.; Lavrynenko, S.; Rucki, M.; Siemiatkowski, Z.; Kislitsa, M. Ceramic cutting tools out of nanostructured refractory compounds. Int. J. Refract. Met. H 2017, 68, 142-144. [CrossRef]

4. Wang, D.; Xue, C.; Cao, Y.; Cao, Y.; Zhao, J. Fabrication and cutting performance of an $\mathrm{Al}_{2} \mathrm{O}_{3} / \mathrm{TiC} / \mathrm{TiN}$ ceramic cutting tool in turning of an ultra-high-strength steel. Int. J. Adv. Manuf. Technol. 2017, 91, 1967-1976. [CrossRef]

5. Laine, R.M.; Marchal, J.C.; Sun, H.P.; Pan, X.Q. Nano- $\alpha-\mathrm{Al}_{2} \mathrm{O}_{3}$ by liquid-feed flame spray pyrolysis. Nat. Mater. 2006, 5, 710-712. [CrossRef] [PubMed]

6. Kolodiazhnyi, T.; Annino, G.; Spreitzer, M.; Taniguchi, T.; Freer, R.; Azough, F.; Panariello, A.; Fitzpatrick, W. Development of $\mathrm{Al}_{2} \mathrm{O}_{3}-\mathrm{TiO} 2$ composite ceramics for high-power millimeter-wave applications. Acta Mater. 2009, 57, 3402-3409. [CrossRef]

7. Bartolomé, J.F.; Smirnov, A.; Kurland, H.-D.; Grabow, J.; Müller, F.A. New $\mathrm{ZrO} 2 / \mathrm{Al}_{2} \mathrm{O}_{3}$ nanocomposite fabricated from hybrid nanoparticles prepared by CO2 laser co-vaporization. Sci. Rep. UK 2016, 6, 20589. [CrossRef] 
8. Smirnov, A.; Bartolomé, J.F.; Moya, J.S.; Kern, F.; Gadow, R. Dry reciprocating sliding wear behaviour of alumina-silicon carbide nanocomposite fabricated by ceramic injection molding. J. Eur. Ceram. Soc. 2011, 31, 469-474. [CrossRef]

9. Evans, A.G. Perspective on the development of high-toughness ceramics. J. Am. Ceram. Soc. 1990, 73, 187-206. [CrossRef]

10. Boatemaa, L.; Bosch, M.; Farle, A.-S.; Bei, G.-P.; van der Zwaag, S.; Sloof, W.G. Autonomous high-temperature healing of surface cracks in $\mathrm{Al}_{2} \mathrm{O}_{3}$ containing Ti2AlC particles. J. Am. Ceram. Soc. 2018, 101, 5684-5693. [CrossRef]

11. Ercenk, E.; Guven, B.; Yilmaz, S. Crystallization kinetics of machinable glass ceramics produced from volcanic basalt rock. J. Non-Cryst. Solids 2018, 498, 262-271. [CrossRef]

12. Song, Q.; Zhang, Z.-H.; Hu, Z.-Y.; Yin, S.-P.; Wang, H.; Wang, H.; Cheng, X.-W. Fully dense B4C ceramics fabricated by spark plasma sintering at relatively low temperature. Mater. Res. Express 2018, 5, 105201. [CrossRef]

13. Li, L.; Pu, S.; Liu, Y.; Zhao, L.; Ma, J.; Li, J. High-purity disperse alpha- $\mathrm{Al}_{2} \mathrm{O}_{3}$ nanoparticles synthesized by high-energy ball milling. Adv. Powder Technol. 2018, 29, 2194-2203. [CrossRef]

14. Ghouli, S.; Ayatollahi, M.R.; Bushroa, A.R. Fracture characterization of ceria partially stabilized zirconia using the GMTSN criterion. Eng. Fract. Mech. 2018, 199, 647-657. [CrossRef]

15. Diaz, L.A.; Montes-Moran, M.A.; Peretyagin, P.Y.; Vladimirov, Y.G.; Okunkova, A.; Moya, J.S.; Torrecillas, R. Zirconia-alumina-nanodiamond composites with gemological properties. J. Nanopart. Res. 2014, 16, 2257. [CrossRef]

16. Smirnov, A.; Bartolomé, J.F.; Kurland, H.-D.; Grabow, J.; Müller, F.A. Design of a new zirconia-alumina-Ta micro-nanocomposite with unique mechanical properties. J. Eur. Ceram. Soc. 2016, 99, 3205-3209. [CrossRef]

17. Gutiérrez-González, C.F.; Suarez, M.; Pozhidaev, S.; Rivera, S.; Peretyagin, P.; Solís, W.; Díaz, L.A.; Fernandez, A.; Torrecillas, R. Effect of TiC addition on the mechanical behavior of $\mathrm{Al}_{2} \mathrm{O}_{3}-\mathrm{SiC}$ whiskers composites obtained by SPS. J. Eur. Ceram. Soc. 2016, 36, 2149-2152. [CrossRef]

18. Ighodaro, O.L.; Okoli, O.I. Fracture toughness enhancement for alumina systems: A Review. Int. J. Appl. Ceram. Technol. 2008, 5, 313-323. [CrossRef]

19. Kumar, R.; Chaubey, A.K.; Maity, T.; Prashanth, K.G. Mechanical and Tribological Properties of $\mathrm{Al}_{2} \mathrm{O}_{3}-\mathrm{TiC}$ Composite Fabricated by Spark Plasma Sintering Process with Metallic (Ni, Nb) Binders. Metals 2018, 8, 50. [CrossRef]

20. Godin, N.; Reynaud, P.; R'Mili, M.; Fantozzi, G. Identification of a Critical Time with Acoustic Emission Monitoring during Static Fatigue Tests on Ceramic Matrix Composites: Towards Lifetime Prediction. Appl. Sci. 2016, 6, 43. [CrossRef]

21. Grigoriev, S.N.; Krapostin, A.A. Multilayer composite nanoscale coatings as a method to increase reliability and tool life of cutting tools made of mixed ceramic $\mathrm{Al}_{2} \mathrm{O}_{3}-\mathrm{TiC}$. Mech. Ind. 2016, 17, 704. [CrossRef]

22. Grigoriev, S.; Metel, A. Plasma- and beam-assisted deposition methods. In Nanostructured Thin Films and Nanodispersion Strengthened Coatings; Voevodin, A.A., Shtansky, D.V., Levashov, E.A., Moore, J.J., Eds.; Kluwer Academic Publishers: New York, NY, USA; Boston, MA, USA; Dordrecht, The Netherlands; London, UK; Moscow, Russia, 2004; pp. 147-154, ISBN 9781402022227 (online), ISBN 9781402022203 (print).

23. Farooqui, M.N.; Patil, N.G. A perspective on shaping of advanced ceramics by electro discharge machining. Procedia Manuf. 2018, 20, 65-72. [CrossRef]

24. Kumar, C.S.; Patel, S.K. Effect of WEDM surface texturing on $\mathrm{Al}_{2} \mathrm{O}_{3} / \mathrm{TiCN}$ composite ceramic tools in dry cutting of hardened steel. Ceram. Int. 2018, 44, 2510-2523. [CrossRef]

25. Ninz, P.; Landfried, R.; Kern, F.; Gadow, R. Electrical discharge machining of metal doped Y-TZP/TiC nanocomposites. J. Eur. Ceram. Soc. 2015, 35, 4031-4037. [CrossRef]

26. Selvarajan, L.; Rajavel, J.; Prabakaran, V.; Sivakumar, B.; Jeeva, G. A review paper on EDM parameter of composite material and industrial demand material machining. Mater. Today 2018, 5, 5506-5513. [CrossRef]

27. Smirnov, A.; Peretyagin, P.; Bartolomé, J.F. Wire electrical discharge machining of 3Y-TZP/Ta ceramic-metal composites. J. Alloys Compd. 2018, 739, 62-68. [CrossRef]

28. Díaz, L.A.; Fernández, A.; Okunkova, A.; Solís, W.; Peretyagin, P.; Gotor Martínez, F.J.; Torrecillas, R. Electro conductive alumina nanocomposites from different alumina-carbides mixtures. Matec. Web Conf. 2016, 65, 02003. [CrossRef] 
29. Ji, R.; Liu, Y.; Diao, R.; Xu, C.; Li, X.; Cai, B.; Zhang, Y. Influence of electrical resistivity and machining parameters on electrical discharge machining performance of engineering ceramics. PLoS ONE 2014, 9, 1-9. [CrossRef] [PubMed]

30. Lóh, N.J.; Simão, L.; Jiusti, J.; De Noni Jr., A.; Montedo, O.R.K. Effect of temperature and holding time on the densification of alumina obtained by two-step sintering. Ceram. Int. 2017, 43, 8269-8275. [CrossRef]

31. Tamura, Y.; Moshtaghioun, B.M.; Gomez-Garcia, D.; Rodríguez, A.D. Spark plasma sintering of fine-grained alumina ceramics reinforced with alumina whiskers. Ceram. Int. 2017, 43, 658-663. [CrossRef]

32. Gao, L.; Hong, J.S.; Miyamoto, H.; Torre, S.D.D.L. Bending strength and microstructure of $\mathrm{Al}_{2} \mathrm{O}_{3}$ ceramics densified by spark plasma sintering. J. Eur. Ceram. Soc. 2000, 20, 2149-2152. [CrossRef]

33. Lee, M.; Borom, M.P. Rapid rate sintering of $\mathrm{Al}_{2} \mathrm{O}_{3}-\mathrm{TiC}$ composites for cutting-tool applications. Adv. Ceram. Mater. 1988, 3, 38-44. [CrossRef]

34. Pourali, Z.; Sovizi, M.R.; Yaftian, M.R.; Yaftian, M.R.; Amiri, Z.; Emami, S.M.; Shahed, H.E. Microstructures and Mechanical Behavior of Ti3SiC2 $/ \mathrm{Al}_{2} \mathrm{O}_{3}-\mathrm{Ni}$ Composites Synthesized by Pulse Discharge Sintering. J. Mater. Eng. Perform. 2018, 27, 3600-3609. [CrossRef]

35. Sun, $\mathrm{S}$; $\mathrm{Xu}, \mathrm{Q}$. Fabricating a Novel Intragranular Microstructure for $\mathrm{Al}_{2} \mathrm{O}_{3} / \mathrm{GdAlO} 3$ Ceramic Composites. Materials 2018, 11, 1879. [CrossRef] [PubMed]

36. Xu, Y.; Zielke, P.; Van Nong, N.; Pirou, S.; Reolon, R.; Si, X.; Simonsen, S.B.; Norby, P.; Lühmann, H.; Bensch, W.; et al. Hydrothermal Synthesis, Characterization, and Sintering Behavior of Core-Shell Particles: A Principle Study on Lanthanum Strontium Cobaltite Coated with Nanosized Gadolinium Doped Ceria. Ceramics 2018, 1, 246-260. [CrossRef]

37. Jin, Y.; Han, M.-K.; Kim, S.-J. Na-Doping Effects on Thermoelectric Properties of Cu2-xSe Nanoplates. Appl. Sci. 2018, 8, 12. [CrossRef]

38. Ning, J.; Wu, D.; Zhao, D. Synthesis and Thermoelectric Properties of TiO2/Cu2SnSe3 Composites. Appl. Sci. 2017, 7, 1043. [CrossRef]

39. Alleno, E. Review of the Thermoelectric Properties in Nanostructured Fe2Val. Metals 2018, 8, 864. [CrossRef]

40. Zhang, H.; Zhang, L.; Liu, X.; Chen, Q.; Xu, Y. Effect of Zr Addition on the Microstructure and Mechanical Properties of CoCrFeNiMn High-Entropy Alloy Synthesized by Spark Plasma Sintering. Entropy 2018, 20, 810. [CrossRef]

41. Viswanathan, V.; Laha, T.; Balani, K.; Agarwal, A.; Seal, S. Challenges and advances in nanocomposite processing techniques. Mater. Sci. Eng. R 2006, 54, 121-285. [CrossRef]

42. Suárez, M.; Fernández, A.; Menéndez, J.L.; Torrecillas, R.; Kessel, H.U.; Hennicke, J.; Kirchner, R.; Kessel, T. Challenges and opportunities for spark plasma sintering: A key technology for a new generation of materials. Sinter. Appl. 2013, 13, 319-342. [CrossRef]

43. Wang, L.; Zhang, J.; Jiang, W. Recent development in reactive synthesis of nanostructured bulk materials by spark plasma sintering. Int. J. Refract. Met. H 2013, 39, 103-112. [CrossRef]

44. Grigoriev, S.; Peretyagin, P.; Smirnov, A.; Solís, W.; Díaz, L.A.; Fernández, A.; Torrecillas, R. Effect of graphene addition on the mechanical and electrical properties of $\mathrm{Al}_{2} \mathrm{O}_{3}-\mathrm{SiCw}$ ceramics. J. Eur. Ceram. Soc 2017, 37, 2473-2479. [CrossRef]

45. Miranzo, P.; Moya, J.S. Elastic/plastic indentation in ceramics: A fracture toughness determination method. Ceram. Int. 1984, 10, 147-152. [CrossRef]

46. Smirnov, A.; Bartolomé, J.F. Mechanical properties and fatigue life of ZrO2-Ta composites prepared by hot pressing. J. Eur. Ceram. Soc. 2012, 32, 3899-3904. [CrossRef]

47. Tseng, W.J.; Kao, W.-H. Preparation of Electrically Conductive Calcium Phosphate Composite Foams by Particle-Stabilized Emulsion Route. Ceramics 2018, 1, 319-328. [CrossRef]

48. Huang, J.; Her, S.-C.; Yang, X.; Zhi, M. Synthesis and Characterization of Multi-Walled Carbon Nanotube/Graphene Nanoplatelet Hybrid Film for Flexible Strain Sensors. Nanomaterials 2018, 8, 786. [CrossRef] [PubMed]

49. Xin, B.; Li, S.; Yin, X.; Lu, X. Dynamic Observer Modeling and Minimum-Variance Self-Tuning Control of EDM Interelectrode Gap. Appl. Sci. 2018, 8, 1443. [CrossRef]

50. Salcedo, A.T.; Arbizu, I.P.; Pérez, C.J.L. Analytical Modelling of Energy Density and Optimization of the EDM Machining Parameters of Inconel 600. Metals 2017, 7, 166. [CrossRef] 
51. Peng, L.M.; Li, Z.; Li, H.; Wang, J.H.; Gong, M. Microstructural characterization and mechanical properties of $\mathrm{TiAl}-\mathrm{Al}_{2} \mathrm{Ti}_{4} \mathrm{C}_{2}-\mathrm{Al}_{2} \mathrm{O}_{3}-\mathrm{TiC}$ in situ composites by hot-press-aided reaction synthesis. J. Alloys Compd. 2006, 414, 100-106. [CrossRef]

52. Yasuoka, M.; Erito, M.E.; Hirao, K.; Kanzaki, S. Effect of Dispersed Particle-Size on Mechanical-Properties of Alumina Non-Oxides Composites. Nippon. Seram Kyo Gak 1993, 101, 889-894. [CrossRef]

53. Volosova, M.; Grigoriev, S.; Metel, A.; Shein, A. The Role of Thin-Film Vacuum-Plasma Coatings and Their Influence on the Efficiency of Ceramic Cutting Inserts. Coatings 2018, 8, 287. [CrossRef]

54. Wang, Y.; Luo, F.; Zhou, W.; Zhu, D. Dielectric and Microwave Absorption Properties of TiC- $\mathrm{Al}_{2} \mathrm{O}_{3} / \mathrm{Silica}$ Coatings at High Temperature. J. Electron. Mater. 2017, 46, 5225-5231. [CrossRef]

55. Cuce, E.; Cuce, P.M.; Guclu, T.; Besir, A.; Gokce, E.; Serencam, U. A novel method based on thermal conductivity for material identification in scrap industry: An experimental validation. Measurement 2018, 127, 379-389. [CrossRef]

56. Kuriachen, B.; Lijesh, K.P.; Kuppan, P. Multi Response Optimization and Experimental Investigations into the Impact of Wire EDM on the Tribological Properties of Ti-6Al-4V. Trans. Indian Inst. Met. 2018, 71, 1329-1339. [CrossRef]

57. Takahashi, K.; Kagawa, T.; Tanaka, K.; Kihira, H.; Ushioda, K. Reduction of Contact Resistance on Titanium Sheet Surfaces by Formation of Titanium Carbide and Nitride, and Its Stability in Sulfuric Acid Aqueous Solution. Tetsu Hagane 2018, 104, 264-273. [CrossRef]

58. Metel, A.S.; Grigoriev, S.N.; Melnik, Y.A.; Bolbukov, V.P. Broad beam sources of fast molecules with segmented cold cathodes and emissive grids. Instrum. Exp. Tech. 2012, 55, 122-130. [CrossRef]

59. Sobol', O.V.; Andreev, A.A.; Grigoriev, S.N.; Volosova, M.A.; Gorban, V.F. Vacuum-arc multilayer nanostructured TiN/Ti coatings: Structure, stress state, properties. Met. Sci. Heat Treat. 2012, 54, 28-33. [CrossRef]

60. Vereschaka, A.A.; Grigoriev, S.N. Study of cracking mechanisms in multi-layered composite nano-structured coatings. Wear 2017, 378, 43-57. [CrossRef]

61. Bayer, T.J.M.; Carter, J.J.; Wang, J.-J.; Klein, A.; Chen, L.-Q.; Randall, C.A. Determination of electrical properties of degraded mixed ionic conductors: Impedance studies with applied dc voltage. J. Appl. Phys. 2017, 122, 244101. [CrossRef]

62. Tijo, D.; Kumari, S.; Masanta, M. Ceramic-metal Composite Coating on Steel Using a Powder Compact Tool Electrode by the Electro-Discharge Coating Process. Silicon 2018, 10, 1625-1637.

63. Jimenez, M.J.M.; de Oliveira, R.F.; Shimizu, F.M.; Bufon, C.C.; Rodrigues, V.; Gobbi, Â.L.; Piazzetta, M.H.O.; Jr, A.R. Poole-Frenkel emission on functionalized, multilayered-packed reduced graphene oxide nanoplatelets. Nanotechnology 2018, 29, 505703. [CrossRef] [PubMed]

64. Grigoriev, S.N.; Melnik, Y.A.; Metel, A.S.; Panin, V.V. Broad beam source of fast atoms produced as a result of charge exchange collisions of ions accelerated between two plasmas. Instrum. Exp. Tech. 2009, 52, 602-608. [CrossRef]

65. Grigoriev, S.; Melnik, Y.; Metel, A. Broad fast neutral molecule beam sources for industrial-scale beam-assisted deposition. Surf. Coat. Technol. 2002, 156, 44-49. [CrossRef]

66. Wu, T.; Su, J.; Li, Y.; Zhao, H.; Zhang, Y.; Zhang, M.; Wu, B. Wear Resistance Mechanism of Alumina Ceramics Containing Gd2O3. Materials 2018, 11, 2054. [CrossRef] [PubMed]

67. Metel, A.; Bolbukov, V.; Volosova, M.; Grigoriev, S.; Melnik, Y. Source of metal atoms and fast gas molecules for coating deposition on complex shaped dielectric products. Surf. Coat. Technol. 2013, 225, 34-39. [CrossRef]

68. Wang, R.; Shi, T.; Zhang, X.; Wang, W.; Wei, J.; Lu, J.; Zhao, X.; Wu, Z.; Cao, R.; Long, S.; et al. Bipolar Analog Memristors as Artificial Synapses for Neuromorphic Computing. Materials 2018, 11, 2102. [CrossRef] [PubMed]

69. Goodall, P.; Foulkes, M.E.; Ebdon, L. Slurry nebulization inductively coupled plasma spectrometry-the fundamental parameters discussed. Spectrochim. Acta B 1993, 48, 1563-1577. [CrossRef]

70. Patil, S.P.; Murkute, R.; Shirafkan, N.; Markert, B. Deformation of Stacked Metallic Sheets by Shock Wave Loading. Metals 2018, 8, 679. [CrossRef]

71. Grigoriev, S.N.; Kozochkin, M.P.; Sabirov, F.S.; Kutin, A.A. Diagnostic Systems as Basis for Technological Improvement. Proc. CIRP 2012, 1, 599-604. [CrossRef]

72. Kozochkin, M.P.; Porvatov, A.N.; Sabirov, F.S. Vibration Testing of Technological Processes in Automated Machining Equipment. Meas. Technol. 2014, 56, 1414-1420. [CrossRef] 
73. Grigoriev, S.N.; Sinopalnikov, V.A.; Tereshin, M.V.; Gurin, V.D. Control of parameters of the cutting process on the basis of diagnostics of the machine tool and workpiece. Meas. Technol. 2012, 55, 555-558. [CrossRef]

74. Ma, L.; Wang, Y.; Di, G. Study on the Microstructure Evolution and Tungsten Content Optimization of 9Cr-3W-3Co Steel. Materials 2018, 11, 2080. [CrossRef] [PubMed] 